\title{
Current status of the anterior middle superior alveolar anesthetic injection for periodontal procedures in the maxilla
}

\author{
Abdul Ahad', Ekramul Haque', Shruti Tandon² \\ 'Department of Periodontics, Dr. Ziauddin Ahmad Dental College, Faculty of Medicine, Aligarh Muslim University, Aligarh, India \\ 2Department of Periodontics, Maulana Azad Institute of Dental Sciences, New Delhi, India
}

\begin{abstract}
Periodontal procedures require adequate anesthesia not only to ensure the patient's comfort but also to enhance the operator's performance and minimize chair time. In the maxilla, anesthesia is often achieved using highly traumatic nerve blocks, apart from multiple local infiltrations through the buccal vestibule. In recent years, anterior middle superior alveolar (AMSA) field block has been claimed to be a less traumatic alternative to several of these conventional injections, and it has many other advantages. This critical review of the existing literature aimed to discuss the rationale, mechanism, effectiveness, extent, and duration of AMSA injections for periodontal surgical and non-surgical procedures in the maxilla. It also focused on future prospects, particularly in relation to computer-controlled local anesthetic delivery systems, which aim to achieve the goal of pain-free anesthesia. A literature search of different databases was performed to retrieve relevant articles related to AMSA injections. After analyzing the existing data, it can be concluded that this anesthetic technique may be used as a predictable method of effective palatal anesthesia with adequate duration for different periodontal procedures. It has additional advantages of being less traumatic, requiring lesser amounts of local anesthetics and vasoconstrictors, as well as achieving good hemostasis. However, its effect on the buccal periodontium appears highly unpredictable.
\end{abstract}

Keywords: Anesthetics, Local; Maxilla; Pain; Palate; Periodontal Debridement.

This is an Open Access article distributed under the terms of the Creative Commons Attribution Non-Commercial License (http://creativecommons.org/licenses/by-nc/4.0/) which permits unrestricted non-commercial use, distribution, and reproduction in any medium, provided the original work is properly cited.

\section{INTRODUCTION}

Dental fear is reported to be present in about $40 \%$ of the adult population [1] and is one of the most common reasons for patients to avoid dental treatments [2]. As of now, we have been successful in providing almost pain-free dental treatment by using different anesthetic techniques, but the target of truly pain-free administration of local anesthesia has not yet been achieved. Unfortunately, this is the common reason why many patients have a greater fear of the pain of anesthetic injections than that of the pain during the treatment procedure itself [2].

Pain associated with local anesthetic (LA) injection may be caused by the mechanical trauma of needle insertion, rapid distension of tissues by the LA solution, or rapid delivery of the contents of the syringe [3]. Minimal discomfort during the administration of local anesthesia is important for building the confidence of the patient towards the clinician, particularly in periodontal therapy, which often requires regular postoperative visits

Received: December 4, 2018 • Revised: January 22, 2019 • Accepted: January 29, 2019

Corresponding Author: Abdul Ahad, Department of Periodontics, Dr. Ziauddin Ahmad Dental College, Aligarh Muslim University, Aligarh - 202002, India

Phone: +919582439639 E-mail: aahad.amu@gmail.com

Copyright(C) 2019 Journal of Dental Anesthesia and Pain Medicine 
for supportive care and maintenance.

Management of periodontal diseases requires the manipulation of the hard and soft tissues in surgical as well as non-surgical procedures. In most patients, the administration of local anesthesia is required to prevent pain. It also ensures minimal discomfort and anxiety for both the patient and the operator. Thorough debridement in the management of inflammatory periodontal diseases requires profound anesthesia of the soft and hard tissues around the affected teeth. The vasoconstrictor present in the LA solution contributes to the hemostasis, which is critically important in mucogingival surgery, particularly while harvesting a graft from the palate.

Performing any periodontal procedures in the maxillary arch requires highly painful and traumatic injections like greater palatine (GP) and/or nasopalatine (NP) nerve blocks for palatal anesthesia. On the buccal aspect, posterior superior alveolar (PSA), middle superior alveolar (MSA), and anterior superior alveolar (ASA) nerve blocks are required [4]. Some patients, however, may require infraorbital (IO) nerve blocks for advanced surgical procedures including ridge augmentation in the anterior maxilla, e.g., ridge expansion, ridge split, or guided bone regeneration. Injections through the buccal vestibule for either the nerve blocks (ASA, MSA, PSA, or IO) or local infiltrations may also affect the muscles of facial expression, the upper lip, part of the nose, and the lower eyelid [5]. Unwanted anesthesia of the upper lip and facial muscles negatively affects speech and smile, and may result in self-inflicted injury while eating $[5,6]$. The anterior middle superior alveolar (AMSA) injection has been reported to be a less traumatic alternative to many of these conventional anesthetic techniques [2]. Although it has been more than two decades since Friedman and Hochman introduced the AMSA injection in 1997 [4], the available data regarding the extent and effectiveness of this injection remain controversial. The application of AMSA injections in endodontic and restorative procedures has been widely explored by assessing pulpal anesthesia; however, very limited data are available regarding its effect on the periodontium.
This review aimed to analyze the existing literature for evidence about the rationale, mechanism, effectiveness, extent, and duration of AMSA injections for periodontal procedures.

\section{METHODS}

A literature search of PubMed and Google Scholar was conducted for relevant articles published up to October 2018. Keywords used for the literature search were "AMSA", "Anterior Middle Superior Alveolar", "Wand ${ }^{\mathbb{R}, ", ~}$ "Computer-Controlled Local Anesthesia" "Scaling and Root planing", "Palatal anesthesia", "Periodontal treatment", "Non-surgical periodontal therapy", and "Maxillary Periodontal Surgery". Clinical and comparative studies, reviews, case reports, and case series related to AMSA injections published in English were included. References of the selected articles were also explored to identify other relevant literature. All the articles were selected without any inclusion or exclusion criteria. Seven articles ( 3 case series and 4 controlled clinical trials) related to AMSA injections in periodontal procedures were extensively reviewed, including their methodology and results (Table 1).

\section{LOCAL ANESTHESIA FOR PERIODONTAL PROCEDURES IN THE MAXILLA: THE AMSA INJECTION}

To achieve anesthesia of the maxillary teeth, periodontium, and palate, different techniques can be employed. These involve deposition of the LA solution around the main trunk of the nerve or a supraperiosteal injection in a particular area for anesthetizing small terminal nerve endings. GP, NP, PSA, MSA, and ASA nerve blocks can be used for anesthetizing the whole quadrant; however, an important potential complication of PSA nerve block is hematoma formation. As alternatives, GP, NP, and IO nerve blocks can be used to adequately reduce the number 
Table 1. Articles on the application of AMSA injections in periodontal procedures

\begin{tabular}{|c|c|c|c|c|c|c|}
\hline $\begin{array}{l}\text { Authors } \\
\text { and year of } \\
\text { publication }\end{array}$ & $\begin{array}{c}\text { Type of } \\
\text { article and } \\
\text { number of } \\
\text { patients }\end{array}$ & Materials and methods & $\begin{array}{l}\text { Type of periodontal } \\
\text { procedure(s) performed }\end{array}$ & $\begin{array}{l}\text { Effectiveness, extent, and } \\
\text { benefits of the AMSA injection }\end{array}$ & Limitations & Conclusion \\
\hline $\begin{array}{l}\text { Loomer and } \\
\text { Perry (2004) } \\
\text { [15] }\end{array}$ & $\begin{array}{l}\text { - Split-mouth } \\
\text { randomized } \\
\text { controlled } \\
\text { clinical trial } \\
\text { - } 20 \text { patients }\end{array}$ & $\begin{array}{l}\text { - Compared the pain in AMSA } \\
\text { injections using Wand and } \\
\text { conventional injections } \\
\text { using conventional syringes } \\
\text { - } 2 \% \text { Lignocaine with } \\
\text { epinephrine (1:100000) } \\
\text { - Recorded the VAS and VRS } \\
\text { scores }\end{array}$ & $\begin{array}{l}\text { - Scaling and root planing } \\
\text { (SRP) }\end{array}$ & $\begin{array}{l}\text { - Pain scores reported for AMSA } \\
\text { injections were significantly } \\
\text { lower than the mean scores of } \\
\text { the conventional injections it } \\
\text { replaced. } \\
\text { - Only one out of } 19 \text { AMSA } \\
\text { injections needed reinforcement. }\end{array}$ & $\begin{array}{l}\text { - PSA block was } \\
\text { also } \\
\text { administered } \\
\text { with each } \\
\text { AMSA injection. }\end{array}$ & $\begin{array}{l}\text { Both AMSA injections } \\
\text { using Wand and the } \\
\text { conventional set of } \\
\text { injections using } \\
\text { conventional syringes } \\
\text { provided anesthesia } \\
\text { of sufficient depth and } \\
\text { duration to allow } \\
\text { adequate SRP. }\end{array}$ \\
\hline $\begin{array}{l}\text { Holtzclaw } \\
\text { and } \\
\text { Toscano } \\
\text { (2008) } \\
{[17]}\end{array}$ & $\begin{array}{l}\text { - Case series } \\
\text { - } 5 \text { patients }\end{array}$ & $\begin{array}{l}\text { - Conventional syringe } \\
\text { - } 27 \text {-gauge needle } \\
\text { - } 4 \% \text { Articaine with } \\
\text { epinephrine }(1: 100000)\end{array}$ & $\begin{array}{l}\text { - Harvesting of connective } \\
\text { tissue graft from the } \\
\text { palate } \\
\text { - Exposure of the impacted } \\
\text { tooth } \\
\text { - Open-flap debridement } \\
\text { (OFD) } \\
\text { - Osseous surgery with an } \\
\text { apically repositioned flap } \\
\text { - Crown-lengthening and } \\
\text { harvesting of connective } \\
\text { tissue graft from the } \\
\text { palate }\end{array}$ & $\begin{array}{l}\text { - Adequate hemostasis } \\
\text { - Buccal tissues were also } \\
\text { anesthetized. } \\
\text { - No "lip drooping" } \\
\text { - Duration of anesthesia up to } 90 \\
\text { min }\end{array}$ & $\begin{array}{l}\text { - Two cases } \\
\text { required } \\
\text { additional } \\
\text { infiltration } \\
\text { around the } \\
\text { central incisors. }\end{array}$ & $\begin{array}{l}\text { AMSA injections } \\
\text { cannot replace the } \\
\text { traditional dental } \\
\text { anesthetic methods. } \\
\text { However, they may } \\
\text { prove useful in certain } \\
\text { situations. }\end{array}$ \\
\hline $\begin{array}{l}\text { Acharya } \\
\text { et al. (2010) } \\
{[8]}\end{array}$ & $\begin{array}{l}\text { - Case series } \\
\text { - } 50 \text { patients }\end{array}$ & $\begin{array}{l}\text { - Conventional syringe } \\
\text { - } 27 \text {-gauge needle } \\
\text { - } 2 \% \text { Lignocaine with } \\
\text { epinephrine }(1: 80000)\end{array}$ & $\begin{array}{l}\text { - OFD } \\
\text { - Resective osseous } \\
\text { surgery } \\
\text { - Gingivectomy }\end{array}$ & $\begin{array}{l}\text { - Extent of anesthesia till the last } \\
\text { standing molar in the quadrant } \\
\text { - Duration of anesthesia was } 90 \\
\text { to } 180 \text { min. } \\
\text { - Blanching of the palatal mucosa } \\
\text { crossed the midline. }\end{array}$ & $\begin{array}{l}\text { - } 12 \text { patients } \\
(24 \%) \text { required } \\
\text { additional } \\
\text { infiltration on } \\
\text { the labial aspect } \\
\text { of the anterior } \\
\text { teeth. }\end{array}$ & $\begin{array}{l}\text { AMSA injections } \\
\text { alone can be sufficient } \\
\text { to carry out } \\
\text { periodontal surgery in } \\
\text { the maxilla. }\end{array}$ \\
\hline $\begin{array}{l}\text { Shirmoham } \\
\text { madi et al. } \\
(2012) \\
{[19]}\end{array}$ & $\begin{array}{l}\text { - Split-mouth } \\
\text { randomized } \\
\text { controlled } \\
\text { clinical trial } \\
\text { - } 20 \text { patients }\end{array}$ & $\begin{array}{l}\text { - Conventional syringe } \\
\text { - } 27 \text {-gauge needle } \\
\text { - } 2 \% \text { Lignocaine with } \\
\text { epinephrine }(1: 80000) \\
\text { - Compared the pain in AMSA } \\
\text { injections and in local } \\
\text { infiltrations by using the VAS }\end{array}$ & - OFD on the palatal aspect & $\begin{array}{l}\text { - No significant difference in pain } \\
\text { during injection } \\
\text { - Postoperative pain was } \\
\text { significantly more on the } \\
\text { infiltration site. }\end{array}$ & $\begin{array}{l}\text { - Extent and } \\
\text { effectiveness of } \\
\text { AMSA } \\
\text { injections were } \\
\text { not reported. }\end{array}$ & $\begin{array}{l}\text { The AMSA technique } \\
\text { could be } \\
\text { recommended for } \\
\text { palatal anesthesia in } \\
\text { periodontal surgery. }\end{array}$ \\
\hline $\begin{array}{l}\text { Shah et al. } \\
(2012) \\
{[16]}\end{array}$ & $\begin{array}{l}\text { - Split-mouth } \\
\text { controlled } \\
\text { clinical trial } \\
\text { - } 10 \text { patients }\end{array}$ & $\begin{array}{l}\text { - Compared the pain in AMSA } \\
\text { injections using Wand and } \\
\text { conventional syringes } \\
\text { - } 30 \text {-gauge needle } \\
\text { - } 0.9 \mathrm{ml} \text { of } 2 \% \text { Lignocaine with } \\
\text { epinephrine }(1: 100000)\end{array}$ & - OFD & $\begin{array}{l}\text { - In the Wand group, complete } \\
\text { palatal anesthesia was reported } \\
\text { by } 100 \% \text { of patients immediately } \\
\text { and } 10 \text { min after injection. } \\
\text { - In the conventional syringe group, } \\
\text { complete palatal anesthesia was } \\
\text { reported by } 80 \% \text { of patients } \\
\text { immediately and by } 100 \% \text { of } \\
\text { patients after } 10 \text { min. } \\
\text { - Blanching of the palatal mucosa } \\
\text { did not cross the midline. }\end{array}$ & $\begin{array}{l}\text { - Anesthesia of the } \\
\text { marginal gingiva } \\
\text { on the buccal } \\
\text { aspect was } \\
\text { reported in only } \\
40 \% \text { of patients } \\
\text { in the Wand } \\
\text { group and } 20 \% \\
\text { of patients in the } \\
\text { conventional } \\
\text { syringe group. }\end{array}$ & $\begin{array}{l}\text { - No significant } \\
\text { difference in pain } \\
\text { between the two } \\
\text { techniques for } \\
\text { AMSA injections }\end{array}$ \\
\hline $\begin{array}{l}\text { Patel et al. } \\
\text { (2012) } \\
{[13]}\end{array}$ & $\begin{array}{l}\text { - Case series } \\
\text { - } 6 \text { patients }\end{array}$ & $\begin{array}{l}\text { - Conventional syringe } \\
\text { - } 27 \text {-gauge needle } \\
\text { - } 2 \% \text { Lignocaine with } \\
\text { epinephrine }(1: 80000)\end{array}$ & $\begin{array}{l}\text { - SRP } \\
\text { - OFD } \\
\text { - Harvesting of free gingival } \\
\text { graft (FGG) }\end{array}$ & $\begin{array}{l}\text { - Good hemostasis achieved, } \\
\text { facilitating the fast and easy } \\
\text { retrieval of FGG } \\
\text { - Duration of anesthesia was } 55 \\
\text { to } 65 \mathrm{~min} \text {. }\end{array}$ & $\begin{array}{l}\text { - Two cases } \\
\text { required } \\
\text { additional } \\
\text { infiltration: } 1 \\
\text { around the } \\
\text { canine and } \\
\text { another around } \\
\text { the incisors. }\end{array}$ & $\begin{array}{l}\text { - AMSA injections can } \\
\text { be utilized in SRP, } \\
\text { FGG harvesting, and } \\
\text { OFD for localized } \\
\text { defects. }\end{array}$ \\
\hline
\end{tabular}


Table 1. Continued

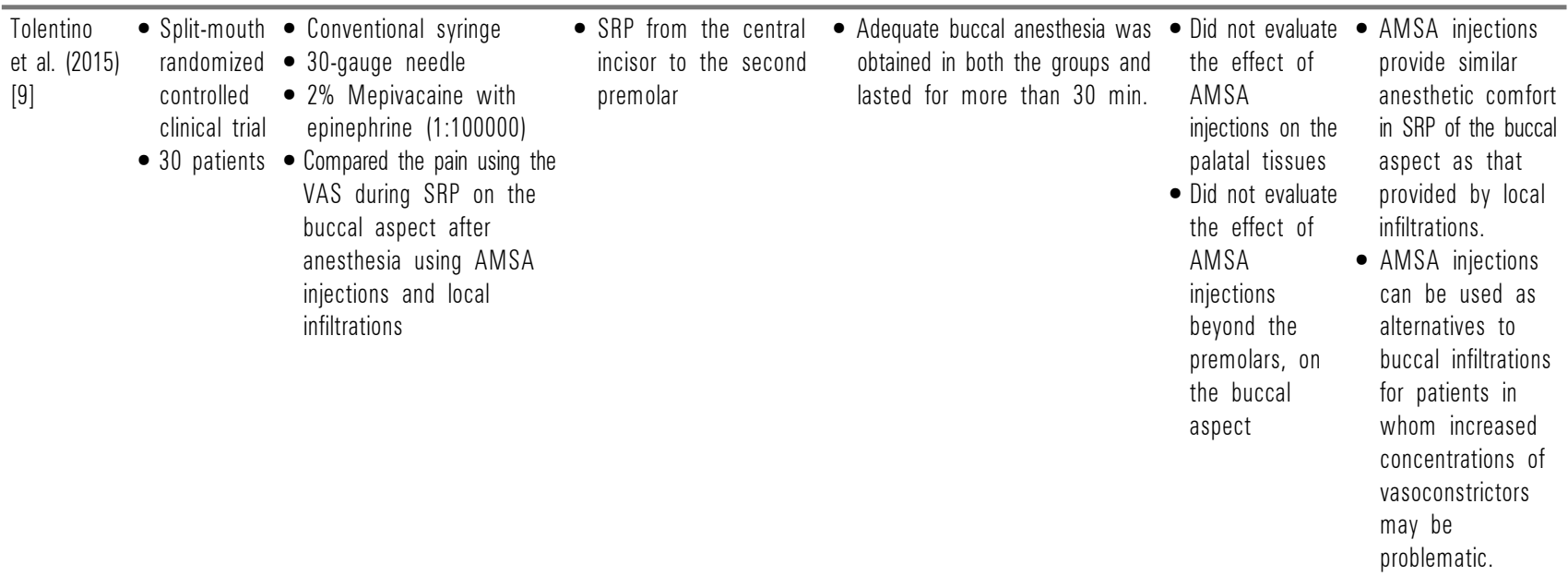
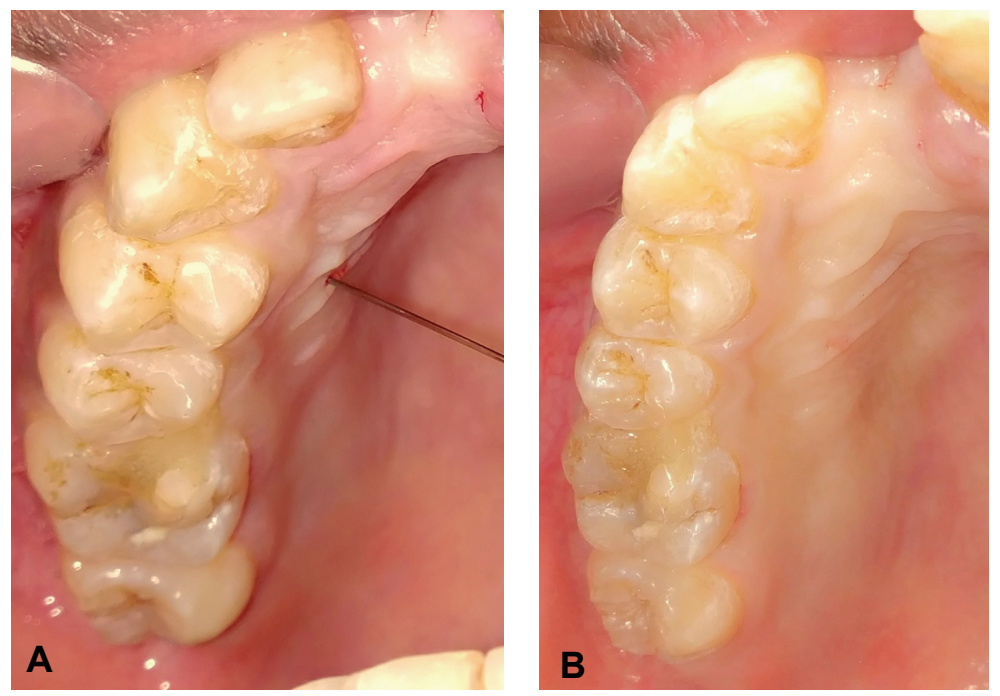

Fig. 1. Photographs showing the anterior middle superior alveolar (AMSA) injection given using a conventional syringe with a 27-gauge needle (Septoject; Sofic, Mazamet, France) and a $2 \%$ lignocaine cartridge (Lignospan Special; Septodont, Saint-Maur-des-Fossés, France). (A) The site of AMSA injection. (B) Blanching of the palatal mucosa suggests the extent of anesthesia obtained using the AMSA injection.

of injections and volume of the LA solution. Supraperiosteal infiltration results in the administration of large volumes of the LA solution along with the vasoconstrictor. This may result in a higher risk of local and systemic complications. Therefore, despite being less traumatic, supraperiosteal infiltration is not recommended when a large area or the whole quadrant needs to be anesthetized.

The AMSA injection is a field block administered from the palatal aspect and is targeted at the subneural dental plexus. As described by Friedman and Hochman in 1997, the site of injection lies between the first and second premolars, halfway from the midpalatine raphe to the gingival margin (Fig. 1A) [4-6,7].

Mechanism: This anesthetic injection requires a little amount of the LA solution ( 0.6 to $0.9 \mathrm{ml})$ to be deposited near the apices of the premolars, from where it diffuses through the nutrient canals and porous bone to envelop the subneural dental plexus [2,7]. This results in anesthesia of the area supplied by the PSA, MSA, and ASA nerves [7-9]. Additionally, the LA solution diffuses beneath the mucoperiosteum of the palate and reaches the branches of the GP and NP nerves. Therefore, it also 
provides anesthesia to most of the palatal hard and soft tissues [10].

Technique: The patient is placed in a supine position with slight hyperextension of the head and neck. After application of a topical anesthetic at the injection site for $1 \mathrm{~min}$, the needle bevel is placed against the palatal tissue and rotated in an axial manner $\left(45^{\circ}\right.$ clockwise and $45^{\circ}$ counterclockwise) for needle insertion. It is important to inject the anesthetic solution at a uniformly slow rate (0.5 $\mathrm{ml} / \mathrm{min}$ ) [11]. Once an adequate amount of the LA is deposited, the operator should wait for $10 \mathrm{~s}$ before removing the needle. This facilitates the dissipation of the LA within the tissue and minimizes dripping during needle withdrawal [7].

Onset and duration of anesthesia: Friedman and Hochman reported that each injection required approximately $90 \mathrm{~s}$ to administer and the teeth were fully anesthetized within 2 min. The duration of anesthesia lasted between 45 and $90 \mathrm{~min}$ [4]. Lee et al. found a gradual onset time ranging from 9 to $26 \mathrm{~min}$, with anesthesia lasting for around 60 $\mathrm{min}$. They evaluated the effect of anesthesia by using an electric pulp tester [7]. In another study by Velasco and Soto on 31 adult patients, the anesthetic induction time of AMSA injections using conventional syringes ranged from 6 to $12 \mathrm{~min}$, and the duration of pulpal anesthesia ranged between 23 and $40 \mathrm{~min}$ [12]. However, for periodontal procedures, the duration of anesthesia using AMSA injections has been reported to be in the range of 55 to $65 \mathrm{~min}$ [13] and 90 to $120 \mathrm{~min}$ [8]. As an exception, Acharya et al. found that in two out of 50 subjects, the effect of anesthesia lasted up to $180 \mathrm{~min}$, especially on the palatal tissues [8]. In general, the duration of periodontal anesthesia appears to be higher than that of pulpal anesthesia.

Effectiveness and extent of anesthesia: There is a wide controversy among the publications regarding the extent of anesthesia achieved using AMSA injections. Freidman and Hochman were the first to report that its effect extends from the central incisor to the mesiobuccal root of the first molar [4]. However, most of the studies evaluated pulpal anesthesia and found the effect of AMSA injections to be unpredictable for the anterior teeth and premolars. Velasco and Soto reported that it was completely ineffective in any of the teeth in $26.7 \%$ of the patients [12]. Most of the studies reported that whenever it was effective, the extent of pulpal anesthesia was observed from the central incisor to the second premolars, among which the central incisors were found to be least affected $[4,7,12,14]$. However, Velasco and Soto found it to be effective on the palatal soft tissue in $100 \%$ of patients, with its effect extending from the central incisors to the mesial side of the first molars [12]. Nevertheless, the effect of the injection did not cross the midline in any of the above studies.

Studies evaluating AMSA injections for different periodontal procedures have also reported the varying extent of anesthesia. It appears that the injection is effective for the entire ipsilateral palate, i.e., from the midpalatine raphe to the gingival margins (Fig. 1B) [8,15-17]. Acharya et al., however, observed that the blanching crossed the midline in some patients, while most of the patients also experienced the effect of anesthesia on the soft palate [8]. Blanching of the soft palate was also reported by Lee et al. [7]. As far as the anesthesia on the buccal periodontium is concerned, the existing literature suggests that the AMSA injection alone is insufficient. Patients often required additional infiltrations and blocks for the anterior teeth $[8,13,17]$ and molars [15], respectively. Tolentino et al., however, reported that the AMSA injection was as effective as local infiltration for anesthesia of the buccal tissues extending from the central incisors through to the premolars [9]. Only one study reported that the AMSA injection was completely effective in the buccal periodontium of the molars [8].

Advantages and disadvantages: Various advantages of this technique over the conventional nerve blocks and supraperiosteal infiltrations have been reported in the 
literature. Most important among these is the reduction in the number of penetrations and cumulative volumes of the LA solution and vasoconstrictor [17]. The higher amount of vasoconstrictor may result in a higher risk of local and systemic complications. Necrosis of the palatal soft tissue may occur when a high concentration of vasoconstrictor is used [6]. Tolentino et al. reported that the amount of LA solution administered in local infiltration was 3 times more than that used in AMSA injections to achieve a similar anesthetic effect [9]. Loomer and Perry found AMSA injections to be less painful and less time consuming than the set of conventional injections they replaced [15]. It also spares the upper lip and muscles of facial expression, thereby ensuring the stability of the smile line during aesthetic procedures in the anterior teeth $[7,18]$. A randomized controlled clinical trial reported that pain during anesthetic delivery using a conventional syringe was significantly less in AMSA injections than in IO nerve blocks for the extraction of the maxillary anterior teeth [11]. Another split-mouth clinical trial reported no significant difference in pain during AMSA injections and local infiltrations for open-flap debridement. However, the postoperative pain was significantly less in the quadrant operated under anesthesia performed using the AMSA injection [19]. Another advantage of using AMSA injections for periodontal procedures is adequate hemostasis on the palate for harvesting soft-tissue grafts $[13,17]$, scaling and root planing (SRP) [16], open-flap debridement, and osseous surgery [17]; in contrast, conventional nerve blocks provide limited hemostasis only in the immediate areas surrounding the injection sites. The disadvantages of AMSA injections include operator fatigue when using a conventional syringe [4] and the frequent need for supplemental anesthesia around the incisors. Rapid injections may also result in ischemia, pain, and ulceration at the injection site [13].

\section{FACTORS AFFECTING THE SUCCESS OF AMSA INJECTIONS}

Anatomical variations in nerve supply: Individual variations in the anatomical nerve pathways in the maxilla are not uncommon, and these affect the successful outcome of different anesthetic injections. In some cases, secondary pulpal innervation may be observed from the GP and NP nerves [20]. This might be a reason for the high success rate of AMSA injections in pulpal anesthesia reported in some studies $[14,18,21]$. The presence of the MSA nerve is highly variable. It may be duplicated [10] in some individuals, while it may be absent in $28 \%$ [22] to $54 \%$ [23] of individuals. Other variations in the anatomy that might affect the outcome of AMSA injections are the course of the MSA and ASA nerves, which are the main contributors to the subneural dental plexus. The MSA nerve may originate from any part of the IO canal, while the ASA nerve mostly originates from the midpoint of the canal [6]. The ASA nerve may also arise near the IO foramen [6]. Since the variations in nerve supply cannot be confirmed in clinical settings, these are major limiting factors in the predictability of anesthetic outcomes of AMSA injections.

Bony porosity and the nutrient canals: The rationale of AMSA injections is based on the dissipation of the LA solution through the numerous nutrient canals in the maxilla. Hence, the outcome could be influenced by the variations in the frequency, distribution, and size of these canals. Porosity and thickness of the palatal cortical bone may also play an important role in the effectiveness and extent of anesthesia [24,25]. Cetkovic et al. used computed tomography and micro-computed tomography to evaluate these variations in 20 human skulls [25]. They found that despite having more thickness, the palatal cortex was more porous than its buccal counterpart in the region of the AMSA injection. The canals that pass through the whole thickness of the cortical bone are the most important structures providing the pathway to the 
subneural dental plexus, which lies in the cancellous bone. The number and width of these canals have also been found to be higher in the palatal cortex than in the corresponding buccal cortex. It is important to note that the foramina of the nutrient canals have been found to be wider in female skulls [25], which may ensure better anesthetic outcomes when using AMSA injections in females than in males. However, Tolentino et al. observed that AMSA injections are less effective than supraperiosteal infiltrations in females [9], suggesting the role of other factors as well. Cetkovic et al. have also reported that in female skulls, the majority of these canals were present in the palatal process, while in the male skulls, most of these canals were in the border zone, i.e., the junction of the alveolar and palatal processes [25]. In view of these findings, the recommended sites of AMSA injection may be changed according to the patient's sex to achieve predictable anesthesia.

Pain threshold of the patient: The perception of pain varies among different individuals because of the difference in their pain threshold. It is affected by several factors like age, sex, stress, anxiety, and previous experience of LA injections $[1,26]$. Even cultural factors can affect the pain perception of an individual [27]. Females, in general, are known to have a lower pain threshold than do males $[28,29]$. It is not surprising that even during AMSA injections, females report more pain than do males [9].

Type of LA drug: Different anesthetic agents have different potential and ability to diffuse through the tissues. Articaine is reported to be 1.5 times more potent than lignocaine, and it has greater ability to diffuse through the tissues owing to its high liposolubility [30]. A meta-analysis also reported that articaine is 3.81 times more likely to achieve anesthetic success than lignocaine, when used for local infiltrations [31].

Saraf et al. compared $2 \%$ lignocaine with adrenaline (1:80000) to $4 \%$ articaine with adrenaline $(1: 100000)$ for AMSA injections as well as IO nerve blocks. They found that articaine was more efficacious than lignocaine for achieving pulpal anesthesia in the maxillary anterior teeth and premolars, irrespective of the injection technique. Articaine also resulted in a faster onset of anesthesia than did lignocaine [30]. Tomić et al. compared the anesthetic efficacy of AMSA injections by using three different anesthetic solutions: $3 \%$ mepivacaine plain, $2 \%$ lignocaine with adrenaline $(1: 80000)$, and $4 \%$ articaine with adrenaline (1:100000). They concluded that predictable efficacy of AMSA injections was achieved for the extraction of the permanent premolars, regardless of the LA used [32]. Both of these studies also reported an insignificant difference in pain on injection with different LA solutions and vasoconstrictors [30,32]. The conflicting results in these two studies regarding the efficacy of different LA solutions for AMSA injections may be attributed to the intended procedure. Saraf et al. used it for root canal therapy and evaluated pulpal anesthesia, while Tomić et al. used it for the extraction of the premolar teeth, which requires additional effect in the periodontium.

Use of the computer-controlled local anesthetic delivery system: Maximum benefits of AMSA injections are achieved when they are administered using the computer-controlled local anesthetic delivery (CCLAD) system $[7,15,16]$. A conventional syringe cannot accomplish the simultaneous high pressure and slow speed required for LA delivery [4]. Therefore, palatal injection has been reported to be more painful when using conventional syringes than when using CCLAD systems $[15,16]$. Hochman et al. also reported that injections performed using CCLAD systems are 2 to 3 times less painful than are conventional injections [33]. In another study, 19 out of 20 patients reported that injection using a CCLAD system was less painful than any injections they had received previously [15]. However, few latter studies reported that both the techniques result in similar pain during AMSA injections [30,32,34].

While using a conventional syringe, it is difficult for the operator to apply a constant pressure for a long time 
while maintaining the recommended speed of LA delivery at $0.5 \mathrm{ml} / \mathrm{min}$. CCLAD systems ensure this unique setting of a constant high pressure along with the simultaneous slow rate of volume flow [4]. Although it takes 4 to 5 min to complete the injection process by using a CCLAD system, it is virtually pain-free $[4,7]$. A rapid injection tends to displace the tissues, whereas CCLAD directs the solution through the connective tissue, periosteum, cortical bone, and medullary bone [4].

Many CCLAD systems are currently available in the market. However, the Wand ${ }^{\mathbb{R}}$ (Milestone Scientific Inc, Livingston, NJ, USA) was the first device developed for this purpose and is the most commonly reported in the scientific literature [2].

\section{STATUS OF THE AMSA INJECTION IN PERIODONTAL PROCEDURES}

Limited data are currently available regarding the application of AMSA injections in periodontal procedures. A comprehensive summary of the relevant publications has been presented in Table 1. Some important findings, apart from those mentioned in the table are discussed below.

Loomer and Perry suggested that the anesthesia obtained using AMSA injections with or without CCLAD was adequate to permit a high level of mechanical therapy, i.e., SRP, which was evident as reduced gingival bleeding and improved clinical attachment level [15]. Although AMSA injections using a CCLAD system require more time to administer, fewer injections are needed to achieve adequate anesthesia for a single quadrant, thus resulting in an almost equal time to that required for conventional nerve blocks and infiltrations [15].

Considering the current status of evidence, the comparatively newer technique of AMSA injection cannot be recommended to replace all conventional anesthetic techniques in the maxilla. Since many studies and case reports have found that AMSA injections almost always anesthetize the whole ipsilateral palate with a few exceptions, provides good hemostasis, is less painful than the alternative GP and NP nerve blocks, reduces the total amount of LA solution and vasoconstrictor, and rarely produces any local or systemic complications, it can be recommended as the first line of anesthesia for the palatal aspect. Moreover, if administered using a CCLAD system or a well-controlled conventional technique, a supplementary injection will be rarely required.

Although the effect of AMSA injections on the buccal periodontium has been observed in several studies [8,9,15-17], its overall predictability is low in most of the cases, especially when compared to injections on the palatal tissues. Nevertheless, it is imperative that one should wait for at least $5 \mathrm{~min}$ for the effect of an AMSA injection on the buccal aspect and administer appropriate nerve blocks or local infiltrations only in the areas that are inadequately anesthetized.

\section{CONCLUSION}

Considering the currently available data, it appears that AMSA injections offer significant advantages over conventional techniques. They significantly reduce the pain and anxiety associated with the highly traumatic NP and GP nerve blocks, and help maintain better hemostasis. AMSA injections become even more predictable and effective when delivered using a CCLAD system. This injection anesthetizes the palatal tissue with high predictability and can therefore be used as the first option for periodontal procedures in the maxilla. However, its effect is unpredictable in the buccal periodontium, which often requires supplementary infiltrations and/or nerve blocks. Since very limited data are available regarding the use of AMSA injections for periodontal procedures in the maxilla, controlled clinical trials with large sample sizes need to be performed to obtain conclusive findings. Its effectiveness can also be explored for various surgical procedures in oral implantology. Since CCLAD systems offer a less-traumatic option, particularly for palatal 
injections, it is strongly advisable to incorporate these in all future studies. This will also ensure the standardization of data and help in the comparison of results obtained in different trials. Without using CCLAD for any palatal injection, it appears difficult to reach the target of pain-free delivery of anesthesia in patients undergoing periodontal procedures.

\section{AUTHOR ORCOIS}

Abdul Ahad: https://orcid.org/0000-0002-6963-9481

Ekramul Haque: https://orcid.org/0000-0001-8538-4127

Shruti Tandon: https://orcid.org/0000-0002-0524-099X

CONFLICT OF INTEREST: The authors declare no conflicts of interest.

\section{REFERENCES}

1. Chang H, Noh J, Lee J, Kim S, Koo KT, Kim TI, et al. Relief of injection pain during the delivery of local anesthesia by computer-controlled anesthetic delivery system for periodontal surgery: Randomised clinical controlled trial. J Periodontol 2016; 87: 783-9.

2. Kwak EJ, Pang NS, Cho JH, Jung BY, Kim KD, Park W. Computer-controlled local anesthetic delivery for painless anesthesia: a literature review. J Dent Anesth Pain Med 2016; 16: 81-8.

3. Meechan JG, Howlett PC, Smith BD. Factors influencing the discomfort of intraoral needle penetration. Anesth prog 2005; 52: 91-4.

4. Friedman M, Hochman M. The AMSA injection: A new concept for local anesthesia of maxillary teeth using a computer - controlled injection system. Quintessence Int 1998; 29: 297-303

5. Friedman M, Hochman M. A 21st century computerized injection system for local pain control. Compendium 1997; 18: $995-1003$.

6. Malamed SF. Handbook of Local Anesthesia, 6th ed. St. Louis: Mosby; 2013: 169-224.
7. Lee S, Reader A, Nusstein J, Beck M, Weaver J. Anesthetic efficacy of the anterior middle superior alveolar (AMSA) injection. Anesth Prog 2004; 51: 80-9.

8. Acharya AB, Banakar C, Rodrigues SV, Nagpal S, Bhadbhade S, Thakur SL. Anterior middle superior alveolar injection is effective in providing anesthesia extending to the last standing molar in maxillary periodontal surgery. J Periodontol 2010; 81: 1174-9.

9. de Souza Tolentino L, Barbisan Souza A, Girardi AA, et al. The anesthetic effect of anterior middle superior alveolar technique (AMSA). Anesth Prog 2015; 62: 153-8.

10. Iwanaga J, Tubbs RS. Palatal injection does not block the superior alveolar nerve trunks: correcting an error regarding the innervation of the maxillary teeth. Cureus 2018; 10: e2120.

11. Yadav AK, Singh A, Pradhan L, Jaisani MR, Dongol A, Acharya $\mathrm{P}$, et al. Comparing the anterior middle superior alveolar nerve block and infraorbital nerve block for maxillary anterior teeth anesthesia: A randomized clinical trial. J Oral Maxillofac Surg Med Pathol 2018; 30: 233-7.

12. Velasco I, Soto R: Anterior and middle superior alveolar nerve block for anesthesia of maxillary teeth using conventional syringe. Dent Res J 2012; 9: 535-40.

13. Patel JJ, Asif K, Aspalli S, Gururaja Rao TR. New anesthetic technique in periodontal procedures. J Indian Soc Periodontol 2012; 16: 253-5.

14. Fukayama H, Yoshikawa F, Kohase H, Umino M, Suzuki N. Efficacy of anterior and middle superior alveolar (AMSA) anesthesia using a new injection system: The Wand. Quintessence Int 2003; 34: 537-41.

15. Loomer PM, Perry DA. Computer controlled delivery versus syringe delivery of local anesthetic injections for therapeutic scaling and root planing. J Am Dent Assoc 2004; 135: 358-65.

16. Shah M, Shivaswamy S, Jain S, Tambwekar S. A clinical comparison of pain perception and extent of area anesthetized by Wand ${ }^{(\mathbb{}}$ and a traditional syringe. J Indian Soc Periodontol 2012; 16: 207-12.

17. Holtzclaw D, Toscano N. Alternative anesthetic technique for maxillary periodontal surgery. J Periodontol 2008; 79: 1769-72. 
18. Friedman M, Hochman M. Using AMSA and P-ASA nerve blocks for esthetic restorative dentistry. Gen Dent 2001; 5: 506-11.

19. Shirmohammadi A, Faramarzi M, Lafzi A, Kashefimehr A, Malek S. Comparison of pain intensity of anterior middle superior alveolar injection with infiltration anesthetic technique in maxillary periodontal surgery. J Periodontal Implant Sci 2012; 42: 45-9.

20. Blanton PC, Roda RS. The anatomy of local anesthesia. J Cal Dent Assoc 1995; 23: 55-69.

21. Perry DA, Loomer PM. Maximizing pain control: The AMSA injection can provide anesthesia with fewer injections and less pain. Dimens Dent Hyg 2003; 1: 28-33.

22. Loetscher CA, Walton RE. Patterns of innervation of the maxillary first molar: a dissection study. Oral Surg 1988; 65: 86-90.

23. McDaniel WL. Variations in nerve distributions of the maxillary teeth. J Dent Res 1956; 35: 916-21.

24. Patel JR, Wuehrmann AH. A radiographic study of nutrient canals. Oral Surg Oral Med Oral Pathol 1976; 42: 693-701.

25. Cetkovic D, Antic S, Antonijevic D, Brkovic BMB, Djukic K, Vujaskovic G, Djuric M. Nutrient canals and porosity of the bony palate: A basis for the biological plausibility of the anterior middle superior alveolar nerve block. J Am Dent Assoc 2018; 149: 859-68.

26. Wijk AJ, Hoogstraten J. Anxiety and pain during dental injections. J Dent 2009; 37: 700-4.

27. Defrin R, Eli I, Pud D. Interactions among sex, ethnicity, religion, and gender role expectations of pain. Gender Med 2011; 8: 172-83.
28. Feine JS, Bushnell MC, Miron D, Duncan GH. Sex differences in the perception of noxious heat stimuli. Pain 1991; 44: 255-62.

29. Komiyama O, De Laat A. Tactile and pain thresholds in the intra- and extra-oral regions of symptom-free subjects. Pain 2005; 115: 308-15.

30. Saraf SP, Saraf PA, Kamatagi L, Hugar S, Tamgond S, Patil J. A comparative evaluation of anesthetic efficacy of articaine $4 \%$ and lidocaine $2 \%$ with anterior middle superior alveolar nerve block and infraorbital nerve block: An in vivo study. J Conserv Dent 2016; 19: 527-31.

31. Brandt RG, Anderson PF, McDonald NJ, Sohn W, Peters MC. The pulpal anesthetic efficacy of articaine versus lidocaine in dentistry: A meta analysis. J Am Dent Assoc 2011; 142: 493-504.

32. Tomić S, Simić I, Stanojević M, Janković S, Todorović L. Anterior and middle superior alveolar block is efficient for maxillary premolar teeth extractions regardless of the injection system or anesthetic with adrenaline used. Srp Arh Celok Lek 2016; 144: 470-3.

33. Hochman M, Chiarello D, Bozzi-Hochman C, Lopatkin R, Pergola S. Computerized local anesthetic delivery vs. traditional syringe technique. NY State Dent J 1997; 63: 24-9.

34. Nusstein J, Lee S, Reader A, Beck M, Weaver J. Injection pain and postinjection pain of the anterior middle superior alveolar injection administered with the Wand ${ }^{\circledR}$ or conventional syringe. Oral Surg Oral Med Oral Pathol Oral Radiol Endod 2004; 98: 124-31. 